RAMACHJANKO,

Doctor of Historical Sciences, Professor, Faculty of Philosophy,

Head of Department of Ruthenian Studies, University of Novi Sad, Serbia

SAGAN GALYNA,

Doctor of Historical Sciences, Associate professor, Professor of World History Department, Borys Grinchenko Kyiv University, Ukraine

\title{
THE UNION OF RUSYNS AND UKRAINIANS OF YUGOSLAVIA: CREATION AND FIRST YEARS OF ACTIVITY
}

The article reveals the activity of the Union of Rusyns and Ukrainians of Yugoslavia (since the late 1990s, the Union of Rusyns and Ukrainians of Serbia and Montenegro), which the organization conducted in the first ten years after its creation (May 12, 1990). For the presentation of those studies, the reports of the fellowship were analyzed, which were published in the periodicals of the Union. Other materials of diaspora's periodicals were also used for the study, which reveals the content of the society's work. The Union was formed with the aim of unifying the Ukrainian and Rusyn community not only of Serbia, but also of all their representatives in the post-Yugoslav space. The organizational work of the Union was aimed at supporting ethnic and cultural traditions of Rusyns, Ukrainians, as well as other representatives of national minorities, especially in Serbia. The community carried out its activity in close cooperation with the diplomatic institutions of Ukraine in Serbia, had active communication with colleagues in Ukraine. Its activity in the 90-ies of the twentieth century, the Union of Rusyns and Ukrainians of Serbia and Montenegro demonstrated tolerance and struggle for the preservation of the rights of all national minorities that inhabit the post-Yugoslav space. In the 90 -ies of the twentieth century, through its activities, the Union of Rusyns and Ukrainians of Serbia and Montenegro demonstrated tolerance and struggle for the preservation of the rights of all national minorities that inhabit the post-Yugoslav space.

Keywords: Rusyns; Ukrainians; Serbia; the Union of Rusyns and Ukrainians of Yugoslavia.

Problem definition and its research. More than 20 thousand Rusyns and Ukrainians now live in Serbia. They often conduct joint social and cultural activities, contact with Ukrainian diplomatic institutions. Their ancestors began to move to the Balkans in the middle of the XVIII century from Transcarpathian and Carpathian villages and settlements. For centuries of being far beyond the lands of their origin, Ukrainians and Rusyns preserved their identity by actively supporting their ethnic and religious traditions. Part of Rusyns consider themselves Ukrainians, which preserved the ancient name "Rusyns", while others believe that the Rusyns are a separate East Slavic people. The same trends are observed in the social and cultural life of the Ukrainian- Rusyn Diaspora of Serbia. Thus, in May 1990, the Union of Rusyns and Ukrainians of Yugoslavia was created, which supports the idea that Rusyns in Yugoslavia are part of the Ukrainian people. The current head of the Union of Rusyns-Ukrainians of Serbia, Bogdan Vislavsky, has the same opinion. He also points out that the Serbian authorities tried to promote the separation of the two ethnic groups (Interview with the head). In contrast to the Union and with the support of the Yugoslav government, opponents of the idea of ethnic Ukrainians and Rusyns unity, in December of the same year founded the "Ruska matka" ("Ruska matystia"), which professed the idea of Rusyn's separability. It began cooperation with those Rusyn organizations in Central Europe, which had a negative attitude towards Ukraine [Рамач, 2016: 17].
The purpose of the article is to study the creation and activities of the Union of Rusyns and Ukrainians of Yugoslavia (URUY and since the end of the 1990s the Union of Rusyns and Ukrainians of Serbia and Montenegro).

The statement of basic materials. The Union began its activity on 12 May 1990 as an organization of collective members of Bosnia and Herzegovina (B\&H), Croatia and Serbia. The Union was joined by the Union of Ukrainians of Bosnia (Banya-Luka), the Union of Rusyns and Ukrainians of Croatia (Vukovar), Taras Shevchenko Cultural and Arts Society (Banya-Luka), Ivan Senyuk Cultural and Art Society (Kula), general education school and a gymnasium named after Peter Kuzmyak (Ruski Krstur) and other public organizations. In general, the collective members of the URUY were 37 subjects, and their leaders were considered co-founders of the Union. The most famous among them are Yanko Sabadosh (Belgrade), Vladimir Khromysh (Novi Sad), Simeon Sakach (Novi Sad), Julian Tamash (Vrbas), Slavko Burda (Zagreb), Gabriel Takach (Vukovar) and others [Рамач, 2005: 2].

The Rusyn scientist from Vrbas Julian Tamash led the Union, and Theodor Frytsky and Yevhen Pavlyshyn were chosen his deputies. The purpose of the URUY's activities was to publicly declare and express the national interests of the Rusyns and Ukrainians of Yugoslavia. Members of the Union considered the position of some other organizations to be incorrect and historically unacceptable. We 
talking about "Ruska matystia", which gathered Rusyns without Ukrainians, and the Society of Ukrainian Language, Literature and Culture, which united Ukrainians without Rusyns [Хроніка, 2006:1]. The founders of the Union believed that they could achieve their goal through the provision of equal rights for Ukrainians and Rusyns. The union created a presidium, consisting of 15 people.

The Union worked in nine directions, whose leaderships were carried out by specially created commissions. Thus, activities were carried out in such areas as science, information, international politics, culture, education, preservation of cultural and historical heritage, material and financial business, publishing, agriculture [Румянцев, 2008: 220].

The Union's work is aimed at protecting the idea of historical unity and reciprocity of Rusyns and Ukrainians. The Union began its activities with the celebration of the $100^{\text {th }}$ anniversary of the Ukrainians' resettlement in Prniavor (Bosnia and Herzegovina). Honored guests arrived at the solemn meeting. In particular, it was Greek-Catholic Krychevesky bishop Slavomir Miklovs, and from Ukraine poets Dmitry Pavlychko, Rostislav Bratik and Roman Lubkivsky. On August 22, 1990 in Novi Sad, the Union signed an agreement on cooperation with the company "Ukraine" from Kyiv. On October 11, 1990, the delegation of the Union was received by the member of the SFRY Government Dragutin Zelenovich, with whom the leaders of the Union discussed the main directions of activity of the newly formed organization of Ukrainians of Yugoslavia [Сакач, 2005: 2].

Due to military conflicts that took place in the territory of Yugoslavia in the early 90's of the twentieth century, the Union of Rusyns and Ukrainians in Croatia, in support of Croatia's independence, left the Union (November 15, 1991). It's example was taken over by some other organizations, so URUY abolished the system of collective membership and moved on to the membership of individuals. Then the Union had almost 400 members [Caкач, 2005: 5].

Despite all the difficulties that gave rise to the break-up of the SFRY, the Union of Rusyns and Ukrainians of Yugoslavia tried not to stop its activities, especially in the context of cooperation with Ukraine. The attempt to enlist the support of the country of origin inspired the hope of alleviating the problems that arose among the Ukrainian diaspora in the course of military conflicts in the Yugoslavian expanses. As for the creative intelligentsia from Ukraine, they tried to do everything possible to make the diaspora feel their support and understanding. Then cultural cooperation between Ukraine and the Ukrainian community of Yugoslavia revived. December 13-22, 1991 Kyiv hosted a delegation of the Union consisting of $\mathrm{Y}$. Tamash, E. Kuleba, V. Khromish. The parties signed a plan of cultural cooperation for 1992. From Ukraine side this document was signed by I. Drach.

However, it was not easy to implement the plan because of military events in Yugoslavia, which became even worse in 1992 [Саган, 2012: 394]. Almost all 1992 year has gone on the efforts of the Union and Ukraine, aimed at supporting the Ukrainian population on the Yugoslav territory. Thus, on both sides, there were numerous appeals to the international community with a request to influence the events in Yugoslavia in order to end the suffering of the civilian population, among whom there were a large number of Rusyns and Ukrainians in the conflict zone. The most difficult situation had developed in such settlements as Petrovtsi, Mikloshevtsi and Vukovar [Сакач, 2005: 5]. In addition, cultural events in which Union's members took part, as a rule, were held on the territory of Ukraine or other countries of the world.

In subsequent years, the Union of Rusyns and Ukrainians of Yugoslavia felt the need and the possibility of its expansion. Therefore, on June 24, 1994 the section of the Union was founded in Kotsur, headed by M. Tsap. In addition, on June 30 of the same year, the Youth Section of the Union, headed by Tetyana Malevko, was created. Thus, there was both quantitative and qualitative growth of the Union in the activity's directions.

Regarding the last statement, on February 3, 1996 the Supreme Council of the Union created Commission on economic cooperation. Subsequently, on November 19, 1996, the Union established a section of lawyers and lawyers. Finding sources of funding for the Union in 1996 the Union signed an agreement with the firm "Euroselectra" (Novy Sad) on cooperation and financial assistance, which came from the company's trade activities with Ukraine. The Union, according to the agreement, contributed to the establishment of trade relations between Ukraine and the Federal Republic of Yugoslavia [Значнєйuи подіï..., 2006: 27].

Despite the military events of the 1990s, the Union conducted active cultural activities aimed at cooperation with Ukraine. The establishment of diplomatic relations between the countries facilitated this. In 1993, the Consulate of Ukraine in Yugoslavia was opened in Belgrade. Volodymyr Primachenko became the Consul General, who began cooperation with the members of the Union.

The leadership of the Union conducted considerable work on organizing the study of the Ukrainian language by children from Ukrainian families. The Union helped to overcome the biggest problem - providing textbooks. In 1994, through the Consulate General of Ukraine in Belgrade, the Union received and transferred to the Ukrainian school in Kula 100 alphabet books and as many books for reading [Значнєйши подіï..., 2006: 26-27].

The activities of the Union in 1995 were closely connected with the celebration of the $250^{\text {th }}$ anniversary of the Rusyn resettlement on the Southern Slavs' lands. For this purpose, an organizational council was created, which included Yu. Tamash and J. Ramach from the Union. First of all, on January 28, 1995, the Union proposed to the Organizing Committee to invite a Ukrainian state delegation, representatives of the society "Ukraine", creative collectives from Ukraine, Poland and Slovakia, representatives of Ukrainian public organizations in Serbia, etc. Also, in the context of the anniversary celebration in August 1995, camps of Ukrainian youth (summer school) were held in Ruski Krstur. Special guests visited this camp - the State Transcarpathian People's Choir from Uzhhorod and the ensemble "Lemkovina" from Poland [Сакач, 2002: 2].

A scientific conference was held on the occasion of the celebration in Ruski Krstur. Representatives from Ukraine took part in the forum: professor I.Yushchuk, L.Donets from the Ministry of Nationality and Migration, ethnographer N.Statsenko. I.Yushchuk presented the scientific report "Mykhailo Kovach poetry as a reflection of historical memory". From the Union at the conference were Yu.Tamash, Ya.Sabadosh, J.Ramach, M.Tsap, R.Myz and others.

As part of the celebration of the $250^{\text {th }}$ anniversary, the Union, with the assistance of the Pokraisky Secretariat for the Observance of the Rights of National Minorities, intended to put several commemorative plaques to prominent Ukrainians in Yugoslavia. In particular, they proposed to install signboards on the buildings where were born bishop Dionizii Nyaraadi, Fr. Michael the Wise and Fr. Dura, all originated from the Ruski Krstur. However, 
the Secretariat refused, arguing that this is a matter for local authorities. The book "The Path of Two and a Half Centuries" was also torn off because it did not raise funds, two thirds of which had to come from sponsors from Yugoslavia [Сакач, 2002: 2-3].

The main celebrations took place during August 23 October 1, 1995 in the Ruski Krstur, where the first Ukrainian settlers settled. Representatives from other areas of Vojvodina also attended the celebration. Thus, on May 19-21, 1995, the anniversary was celebrated in the city of Novi Sad. There was organized a thematic exhibition of drawings dedicated to the Ukrainian diaspora, a festive concert with the participation of the ensemble from Ukraine "Novoyavorschina", whose arrival was organized by Fr. R.Myz.

In the middle of the 1990s, a significant event took place, which witnessed the close scientific contacts of the active members of the Union with Ukraine. Thus, in 1995 at the University of Uzhhorod (from 2000 has status of national), the doctoral thesis was defended by Janko Ramach from Novi-Sad University on the topic: "The History of the Rusyns of Southern Hungary" [Рамач, 1995], which was the result of many years of studying the history of Rusynism. Today, the scientist continues fruitful cooperation with Ukrainian colleagues and publish new works on the history of Rusyns-Ukrainians in the Balkans [Paмач, 2016; 2017].

Among other things, 1995 year was accompanied by constant troubles generated by military events on the territory of the former Yugoslav federation. Consul General of Ukraine in Yugoslavia V.Prymachenko and B.Oliynyk Chairman of the Commission on Foreign Relations under the Parliament of Ukraine in May 1995 held consultations with the authorities of the SRY on the problems and needs of the Rusyns and Ukrainians of Yugoslavia. Ukrainian diplomat and parliamentarian insisted on resolving the most painful issue, evicting and resettling Rusyns and Ukrainians from their places of permanent residence. The situation in Croatian Slavonia was complicated. The problem related to Rusyn issues was also raised. V. Prymachenko and $B$. Oliynyk spoke about the need to establish cultural and national identity of the Rusyns as a part of the Ukrainian people [Сакач, 2002: 3].

Since the mid-90s of the $20^{\text {th }}$ century, Ukraine has begun to receive young people from the former Yugoslavia for study in their higher schools. The Union of Rusyns and Ukrainians of Yugoslavia carried out a lot of work in this direction. Thus, in the 1994-1995 academic year, 37 students from Yugoslavia were studying in Ukraine. The following year their number increased by four people. Among them, Ukrainians and Rusyns were 38 people and 1 representative of each nationalities - Serbian, Montenegrin and Slovak [Сакач, 2002: 3]. Citizens of the newly independent Yugoslav republics received higher education in different cities of Ukraine - in Lviv, Kyiv, Ivano-Frankivsk.

Important events filled the activity of URUY in 1996. Thus, in March at the Faculty of Philosophy of the Novi-Sad University, the Department of Ukrainian Language and Literature was opened by the efforts of the members of the Union. At the Faculty of Philosophy in Novi Sad there is only the Department of the Rusyn Language and Literature, where presented one subject - Ukrainian language, and at the Faculty of Philology in Belgrade there is also the Department of Ukrainian Studies. In November 1996, at the Faculty of Philosophy in Novi Sad and with the help of the Serbian-Ukrainian Society, a symposium was organized on the topic: Ivan Franko and the Serbs. From the Union took part in the forum M.Kovac, J.Tamash, J.Ramach,
M.Tsap, D.Latyak and others. At the end of the year, the meeting of the Main Council of the Union was devoted to an important topic, which, according to the Union's members, complicated the life of the Ukrainian community with every year more and more. It is a so-called "Rusyn issue". The Union expressed its protest against the escalation of the problem, attempts to identify Rusyns as a separate people. At the meeting, they decided to once again propose cooperation between the Rusyn and Ukrainian organizations of Yugoslavia, in particular, the "Ruska matka" ("Ruska matystia") and the Ukrainian language, literature and culture community. None of the leaders of these organizations accepted the proposal of the Union [Сакач, 2004: 2]. At the same time, the Union launched an active cooperation with Ukraine.

At the request of the Union in late 1997, the Ukrainian Ambassador V.Prymachenko handed over the next batch (100 copies) of the alphabet books to the Ukrainian school in Vrbas. The Union also published books itself. Thus, the "Chronicle of Ruski Krstur" G.Kostylnyk's work, funded by the Open Society Foundation, was printed in 1998 (Soros Foundation, Novi Sad). In the beginning of 1999, the collection of children's songs "Pupche" by Y.Feysy came out, and in the autumn of that year in Uzhgorod a collection of M. Kovach's "Silent waters" came out at the cost of the Union and timed to its $90^{\text {th }}$ anniversary. Ivan and Mykhailo Chendeiyov worked on the translation of the collection.

The presentation of the book took place on December 17 in Uzhgorod State University. Dozens of guests attended the event. About twenty professors of the University reported about the work of M.Kovach. Also arrived guests from Kyiv for this event. In particular, the corresponding member of the National Academy of Sciences of Ukraine O. Myshanych. He talked about the work of the hero of an anniversary, about the translation of his works. M. Kovach received many congratulatory telegrams on the anniversary. The congratulations were sent by the Institute of Literature of the National Academy of Sciences of Ukraine, the Union of Writers of Ukraine, the Ukraine-World Society, and others. The Transcarpathian Regional Council awarded M. Kovach a certificate of honor for his personal contribution to the establishment of cultural ties between the Rusyns and Ukrainians of Yugoslavia and Transcarpathia [Звum o poбomu..., 2006: 43].

Since 1998, the Union had started work on organizing summer schools for children and young people who wanted to learn their native language. The first such school was supposed to work July 17-26, 1998 in Ruski Krstur. The premises were provided free of charge by the Educational Center "Petr Kuzmyak". It was planned that the government of Serbia would provide money for student meals (75 dinars per person). Therefore, for maintenance of a school with 70 children was necessary 52 thousand dinars. However, the state allocated only 10 thousand dinars, which did not allow the implementation of the plan to open the summer school in 1998 [Діялносц Союзу ..., 2006: 38].

Nevertheless, this failure did not stop the unionists. Some projects they managed to finance. Thus, Nenad Bogdanovych, with the support of the Union in 1998, passed postgraduate practice at P. Chaikovsky Music Academy in Kyiv. At the same time, Maria Deberniy from Vrbas was doing an internship in a research pharmacy at the Pharmaceutical Faculty of the Medical University of Lviv. At the request of the Union, the Ministry of Education of Ukraine, in the academic years 1998-1999, took free training for Olesya Khoma (decorative and applied art), Branka Lukiж (graphic), Bylyana Shypzych (international 
relations) to the Lviv University for the relevant departments [Діялноси Союзу ..., 2006: 39].

In addition to the above, the Union took part in organizing a number of events, some of which were prepared together with colleagues from Ukraine. Thus, in 1997 in Vrbas celebrated the $70^{\text {th }}$ anniversary of the founding of the Union of Rusyns schoolchildren. The same year celebrated the $100^{\text {th }}$ anniversary of the scientific expedition of ethnographer $\mathrm{V}$. Hnatyuk, the $90^{\text {th }}$ anniversary of the birth of a priest from Vrbas - Onufriy Timka. It is interesting that at the jubilee of the last in the church sang a singing choir from the church communities of Vrbas, R. Krstur, Kotsura and Dyurdyov.

Exhibitions organized by the Union were very popular in the Ukrainian diaspora. On July 24 - September 3, 1998, photos of Vasyl Pylypyuk on the Independence Day of Ukraine were displayed at Novi Sad. On February 23, 1999, also in Novi Sad, a celebration of the 185th anniversary of T. Shevchenko's birth was organized. Within the celebration of the jubilee, an exhibition was held at the Museum of Vojvodina, concerts were organized at Novi Sad and Durdevo [Значнєйши події..., 2006: 27].

The cultural activity of the Union was fruitful for 2000 year. During this year, two numbers (No. 2 and 3 ) of the Union's official publication "Voice of the Union" came out. Print of the second number was financed by the Secretariat for ensuring the rights of national minorities, the management and regulations of the Vojvodina Executive Council, which allocated 6 thousand dinars, as well as the sponsorships of the lawyers - Simeon Sakach and Fedir Kolesar (50 dinars from each). The third number of the "Voice of the Union" was issued only for sponsorship funds, allocated by Volodymyr Likar from Novi Sad. Of course, publishing activities were not limited to the issue of the magazine. Thus, the Vrbas section issued Anna Timka's work "Kukharka", which was the second supplemented edition since 1938. The publication was sponsored by the oil factory "Vital" from Vrbas and the refrigerating plant "ABC" from Ruski Krstur [Сакач, 2006: 43].

In May 2000, in Novi Sad, the Union held a solemn celebration on the occasion of the $10^{\text {th }}$ anniversary of its founding. The reports were delivered by the members of the Union Maria Sakach, academician Julian Tamash and Fr. Roman Myz.

Welcoming speech from the guests had Sredoye Lalych - chairman of the Serbian-Ukrainian Society. The concert, dedicated to the anniversary, was attended by the bands "Rosa" and "Bata-Band", whose performance was funded by Mykhailo Bindas and Fr. Roman Myz.

On December 16, 2000, the Union's section and KMT "Dura Kish" from Shida organized literary evening devoted to the writer Mykhailo Kovach on the occasion of his $90^{\text {th }}$ anniversary. The evening was attended by poetess Iryna Garde-Kovachevich, writer Volodymyr Kochish, Union's secretary Simeon Sakach and members of KMT "Dura Kish" from Shida. On May 30, 2000, the Union Section from Novi Sad organized a solemn celebration of the $75^{\text {th }}$ anniversary of the birth of Dura Vargha and the $60^{\text {th }}$ anniversary of his fruitful work aimed at ensuring the wellbeing of his people. Iryna Papuga, Dura Latyak and Simeon Sakach spoke about the Dura Vargha and its activities [Сакач, 2006: 44].

A separate page of the Union of Rusyns and Ukrainians in Serbia and Montenegro is its work in the field of education. With the assistance of the Union from February 14 to June 12,2000 , courses on the study of the Ukrainian language were organized at the Philosophy Faculty in Novi
Sad. Lyudmila Popovych, professor of the Faculty of Philology of the Belgrade University was a teacher. The course was attended by 30 people who received diplomas after graduation. This project was funded by the Pokrainski Secretariat for the implementation of the rights of national minorities, management and regulations in the Autonomous Province of Vojvodina (APV).

On April 20-25, 2000, a seminar for Ukrainian language teachers from the Diaspora took place in Kyiv. With the help of the Union, Maritsa Leshchyshyn from Kula and Volodymyr Rahman from Vrbas, who taught Ukrainian language in those areas, attended the workshop. The travel expenses were paid to them by the Pokrainski Secretariat for the implementation of the rights of national minorities, management and regulations of the APV.

At the request of the Union and with the assistance of the State Committee of Ukraine for Nationalities and Migration, postgraduate study and internship at the Karpenko-Kary Kyiv State Institute of Theatrical Arts was extended for Volodymyr Nadia, a graduate theater director from Ruski Krstur. In the 2000-2001 academic year, with the help of the Union, Miodrag Yelich from Novi Sad was sent to the composer's faculty for free study at the P.Tchaikovsky National Music Academy of Ukraine. Myroslava Amidzich from Rumy, who graduated with honors from the Kyiv National University of Construction and Architecture (Architecture Faculty), was accepted for postgraduate education in this university. The Faculty of Architecture also accepted for free education Fedor Ferench from Sremska Mitrovica [Сакач, 2006: 44].

In Novi Sad, with the assistance and help of the Rusyns and Ukrainians Union of Serbia and Montenegro, the Academic Association of Rusyns and Ukrainians (AARU) was created on May 27, 2000. ATRU had to assume responsibilities related to the activities of diaspora in the field of education and science. One of the first results of the AARU was the participation of its members in the Kyiv Scientific and Practical Conference on "Enlightenment in Ukrainian Foreign: Experience, Situation and Perspectives" on November 4-5, 2000. Ludmyla Popovich from Belgrade, a delegate from the ATRU, delivered a presentation on "The Situation and Prospects for the Development of Ukrainian studios in Serbia" [Сакач, 2006: 44].

During 2000 the Union of Rusyns and Ukrainians of Serbia and Montenegro conducted significant organizational work aimed at expanding its divisions. Along with the existing sections in Ruski Krstur, Kotsury, Vrbas, Novi Sad, Youth Section and the Section of Lawyers, on June 16, 2000, a section of the Union was established in Shydi, headed by Stefan Shchurok; his deputy was elected Vasyl Mudry, and secretary - Sanya Tyrkaylo [Сакач, 2006: 43].

The Union of Rusyns and Ukrainians of Serbia and Montenegro on the protection of the rights of national minorities of Yugoslavia had taken an active part. Thus, at the invitation of the First Minorities Forum "Open Perspectives" from Subotica, which took place on September 8-10, 2000, academician Julian Tamash and journalist Boris Varga participated on behalf of the Union. On November 17 and 18, members of the Union, including Theodore Kolesar, Mykola Shanty, Simeon Sakach and Velimir Paplatko, took part in the Seminar on National Minorities organized by the Federation of European Minorities and the Croatian Democratic Union in Vojvodina on the topic: "The national minorities in Vojvodina, the present situation and prospects".

An important part of the Union's activities was coo- 
peration with state authorities of the SRY, which was a sign of not only organization's active social position, but also in this way the Union tried to defend the interests of representatives of the Ukrainian-Rusyn diaspora. Thus, by the beginning of 2000 , the Union had made a proposal to the regional secretary of P.Domonia to convene a joint meeting of the interested parties for the purpose of concluding agreements on the organization and financial support of the summer school in the Ruski Krstur for Rusyn and Ukrainian children of Vojvodina who did not study their native language optionally. But the joint meeting did not take place, as did the summer school for Rusyn children. The organizers were able only to open the school for Ukrainian children in Banki Petrovac.

On October 3, 2000, without a formal warning, director of the RTV Novi Sad banned broadcasting programs of all editions of national minorities of the Novi Sad TV. The Union had sent a protest to the Minister of Information in the government of the Republic of Serbia and to the Minister without a portfolio - Ivan Sedlak, as well as to the regional secretaries on informing and securing the rights of national minorities, management and regulations with a demand to immediately annul the ban and allow further work of the Rusyn's edition of TV Novi Sad.

Thanks to this communication, on October 5, 2000, the TV Novi Sad editorial board resumed its work. Within ten days, the Union made a proposal to introduce a program in the Ukrainian language on the TV Novi Sad, which was accepted by the channel's management. Also, in October 2000, the Union once again proposed the cultural and educational committee of Serbia to award a Vuk Karadћiж prize to the famous Ukrainian writer of Yugoslavia - Mykhailo Kovach. This proposal was not approved by the leadership of the committee.

On November 16, 2000, the deputy of the Union Minister for National and Ethnic Associations, Elena Markovych, received in Belgrade a delegation from the Union of Rusyns and Ukrainians of Serbia and Montenegro consisting of Maria Sakach, Fedor Kolesar, Mykola Shanty and Velimir Paplatsko, who familiarized the official with the activities and plans of the Union. On December 7, 2000, the same delegation of the Union met with the regional secretary for the protection of national minorities rights, administration and regulations - Tamas Korkhets. During the conversation the members of Union acquainted T. Korkhets with the problems of the Union, identified possible ways to solve them [Сакач, 2006: 44].

In general, Union activists believed that the government and its representatives little contributed to the activities of the Union. As a rule, officials expressed their sympathy, approved the actions of public organizations, but provided neither financial nor legal support, which made it difficult to implement the Union's program [Сакач, 2006: 45].

The mentioned meeting with regional Secretary T.Kortseh was rather an exception - on that meeting the union asked 17 thousand dinars for the meeting of the Union's Main Council and the publication of the fourth number of "Voice of the Union". Already the next day, 5 thousand dinars were transferred to the Union account. Perhaps, such promptness was influenced by the control of the union ministry. The missing amount was provided to Ukrainians by sponsors. Other promises of the authorities were not even partially implemented. In particular, the minister without a portfolio in Serbia, Ivan Sedlak and the regional secretary for the implementation of national minorities rights, the management and regulations - P.Domoni promised to convene a round table of representatives of all Rusyn and Ukrainian organizations to discuss the accumulated problems, but the event never took place [Сакач, 2006: 46].

\section{Conclusions}

Thus, the activity of the Union of Rusyns and Ukrainians of Serbia and Montenegro during the first ten years of its existence is characterized by the following tendencies:

1) The main efforts of the organization were aimed at the consolidation of Ukrainian and Rusyn communities on the southern Slavs' lands, first of all Serbia, for which the Union was created, in fact. Thus, we can assert that the organization from the very first days of its existence coped with its tasks.

2) The organization actively supported the identity of not only Ukrainians and Rusyns of the region, but also at the state level, the Union defended the rights of all national minorities in Serbia.

3) The Union also conducted fruitful cooperation with its colleagues from Ukraine, had established relations with Ukrainian diplomatic institutions. All this work was aimed at ensuring the national needs of the UkrainiansRusyns of the region.

4) At the time of the military conflict in the Balkans, in the first half of the 90's of the twentieth century, the Union with the support of Ukraine and the Embassy, organized a number of humanitarian and cultural events, holding back the massive reimaggration of Ukrainians and Rusyns from the post-Yugoslav area.

\section{REFERENCES}

1. Hronika. 2006. Glas Sojuzu. № 9. S.1 (serb).

2. Dijalnosc Sojuzu u 1998 roku 2006. Glas Sojuzu. №9. S. $38-42$ (serb).

3. Zvit o roboti sojuzu u 1999 roku 2006. Glas Sojuzu. № 9. S. $40-48$ (serb)

4. Znachn€jshi podiï prez 15 roki 2006. Glas Sojuzu. № 9. S. 27 (serb).

5. Interv'yu z golovoyu Soyuzu rusyniv-ukrayinciv Serbiyi Bogdanom Vislavskym 20.10.2017. Availabe at: http://lemky.lviv.ua/ ? $p=5877$ \#more-5877 (Accessed: 5.07.2018)

6. Ramach, Yanko. 1995. Istoriya rusyniv Pivdennoyi Ugorshhyny: avtoref. dys. na zdobuttya nauk. stupenya dok. ist. nauk : 07.00 .02 - vsesvitnya istoriya. Uzhgorod, 52 p. (ukr).

7. Ramach, Yanko. 2016. Na kryzhnem dragy: Rusnacy u Yugoslavyyi od 1918-1941 roku. Ruske slovo, Novy Sad: 381 s. (serb)

8. Ramach, Yanko. 2016. Oglyad istoriyi rusyniv u Yugoslaviyi (1918-2000. Sumska starovyna. Sumskyj derzhavnyj universytet. № XLIX. S. 5-22 (ukr).

9. Ramach, Yanko. 2017. Rusnacy u Novym Sadze od 60-yx rokox XVIII po konyecz XIX vyka. Rusynystychny studyyi. Novy Sad, № 1. S.123-141 (serb).

10. Rumjancev, O. 2008. Galichina - Bosnija - Voevodina: ukrayinski pereselenci z Galichini na teritoriyi jugoslavskih narodiv v 1890-1999 rokah. FADA, LTD, Kiiv: 256 pp. (ukr).

11. Sagan, G. 2012. Yugoslovyany u XX stolitti: gromadski ta kulturni zvyazky z Ukrayinoyu. Kyyivskyj universytet imeni Borysa Grinchenka; Instytut ukrayinskoyi arxeografiyi ta dzhereloznavstva imeni M.S. Grushevskogo NAN Ukrayiny. Kyiv: Un-t im. B. Grinchenka, 568 pp. (ukr).

12. Sakach, S. 2002. Dïjalnosc Sojuzu u 1995 roku. Glas Sojuzu. №5. S.2-4 (serb).

13. Sakach, S. 2004. Dijalnosc Sojuzu u 1996 roku. Glas Sojuzu. № 6-7. S. 2-4 (serb).

14. Sakach, S. 2006. Zvit pro dijalnist Sojuzu za 2000 rik. Glas Sojuzu. №9. S. 43-48 (serb).

15. Sakach, S. 2005. Sojuz posle petnac rokoh. Glas Sojuzu. № 8. S.2-4 (serb). 
Рамач Янко,

доктор історичних наук, професор Відділу русиністики Філософського факультету,

Новосадський університет, Сербія

Саган Галина,

доктор історичних наук, дочент, професор кафедри всесвітньої історії,

Київський університет імені Бориса Грінченка, Украӥна

\section{СОЮЗ РУСИНІВ І УКРАЇНЦІВ ЮГОСЛАВІї: СТВОРЕННЯ ТА ПЕРШІ РОКИ ДІЯЛЬНОСТІ}

Стаття розкриває діяльність Союзу русинів та українців Югославії (з кінця 90-х рр. XX ст. Союз русинів i українців Сербії та Чорногорії), яку організація вела в перші десять років після свого створення (12 травня 1990 р.). Для дослідження теми було проаналізовано звіти товариства, які публікувалися в періодичних виданнях Союзу. Також вивчено інші матеріали періодики діаспори, котрі розкривають зміст роботи товариства, а також інтерв'ю з нинішнім керівником Союзу Богданом Віславським.

На території Сербії нині проживає понад 20 тис. русинів та українців, які досить часто ведуть спільну громадську та культурну діяльність, контактують з українськими дипломатичними інституціями. Їхні предки почали переселятися на Балкани ще в середині XVIII ст. із закарпатських і прикарпатських сіл і селищ. За століття перебування далеко поза землями свого походження українці і русини зберегли свою ідентичність завдяки тому, що активно підтримували свої етнічні та релігійні традиції. Чистина русинів вважає себе українцями, за якими збереглася давня назва «русини», інші дотримуються думки, що русини - окремий східнослов'янський народ. Такі ж тенденції спостерігаються і в громадському та культурному житті українсько-русинської діаспори Сербії. Так, у травні 1990 р. був створений Союз русинів і українців Югославії, який є прибічником ідеї, що русини в Югославії є частиною українського народу. Такої ж думки дотримується нинішній голова Союзу русинів-українців Сербії Богдан Віславський. Основні зусилля організації спрямовувалися на консолідацію української та русинської громад на землях південних слов'ян, насамперед Сербії, власне, задля чого створювався Союз. Таким чином, ми можемо стверджувати, що організація з перших днів свого існування виконувала поставлені завдання.

Робота організації активно підтримувала самобутність не тільки українців та русинів регіону, але й на державному рівні Союз відстоював права усіх національних меншин Сербії. Союз також плідно співпрацював 3 колегами 3 України, мав налагоджені відносини з українськими дипломатичними інституціями. Уся ця робота була спрямована на забезпечення національних потреб українців-русинів регіону. У часи військового конфлікту на Балканах у першій половині 90-х р. XX ст. Союз за підтримки України та Посольства організував низку заходів гуманітарного та культурного характеру, чим стримував масову рееміграцію українців і русинів 3 постюгославського простору.

Ключові слова: русини; українці; Сербія; Союз русинів та українців Югославії.

1. Хроніка. Глас Союзу. 2006. № 9. С.1.

ЛІТЕРАТУРА

2. Діялносц Союзу у 1998 року. Глас Союзу. 2006. №9. С. 38-42.

3. Звит о роботи союзу у 1999 року. Глас Союзу. 2006. № 9. С. 40-48.

4. Значнєйши події през 15 роки. Глас Союзу. 2006. № 9. С. 27.

5. Інтерв'ю з головою Союзу русинів-українців Сербії Богданом Віславським Опубліковано 20/10/2017. URL: http://lemky.lviv.ua/ $? p=5877 \#$ more-5877 (дата звернення: 5.07.2018).

6. Рамач Я. Історія русинів Південної Угорщини: авторефр. дис. ... док. іст. наук : 07.00.02. всесвітня історія. Ужгород, 1995. $52 \mathrm{c}$.

7. Рамач Я. На крижней драги: Руснаци у Югославиї од 1918-1941 року. Нови Сад: Руске слово, 2016. 381 с.

8. Рамач Я. Огляд історії русинів у Югославії (1918-2000). Сумська старовина. Сумський державний університет. 2016. № XLIX. C. 5-22.

9. Рамач Я. Руснаци у Новим Садзе од 60-их рокох XVIII по конєц XIX вика. Русинистични студиї. Нови Сад, 2017. № 1. C.123-141.

10. Румянцев О. Галичина - Боснія - Воєводина: українські переселенці з Галичини на території югославських народів в 1890-1999 роках. Київ: ФАДА, ЛТД, 2008. 256 с.

11. Саган Г. Югослов'яни у XX столітті: громадські та культурні зв'язки з Україною. Київський університет імені Бориса Грінченка; Інститут української археографії та джерелознавства імені М.С. Грушевського НАН України. Київ: ун-т ім. Б. Грінченка, 2012. 568 с.

12. Сакач С. Дїялносц Союзу у 1995 року. Глас Союзу. 2002. №5. С.2-4.

13. Сакач С. Діялносц Союзу у 1996 року. Глас Союзу. 2004. № 6-7. С. 2-4.

14. Сакач С. Звіт про діяльність Союзу за 2000 рік. Глас Союзу. 2006. №9. С. 43-48.

15. Сакач С. Союз после петнац рокох. Глас Союзу. 2005. № 8. С.2-4.

() Рамач Янко, Саган Галина

Надійшла до редакції 11.07.2018 